УДК 657.1

DOI 10.31882/2311-4711.2019.25.14

\author{
Малицкая Виктория Борисовна \\ д.э.н., профессор, кафедра бухгалтерского учета и налогообложения \\ Российский экономический университет имени Г.В.Плеханова, \\ Российская Федерация, г. Москва, 117997, Стремянный пер., 36 \\ E-mail:vmrussian@yandex.ru
}

\author{
Шихатов Павел Иванович \\ аспирант 2 года обучения кафедры бухгалтерского учета и налогообложения, \\ Российский экономический университет имени Г.В.Плеханова, \\ Российская Федерация, г. Москва, 117997, Стремянный пер., 36 \\ старший преподаватель кафедры экономической теории и мировой экономики \\ НОУ ВО Международный Институт Экономики и Права \\ Российская Федерачия, г. Москва, 105082 Рубцовская наб., 3, стр. 1 \\ E-mail:pulivan@yandex.ru
}

\title{
АКТУАЛЬНЫЕ ПРОБЛЕМЫ УЧЕТНОГО ОБЕСПЕЧЕНИЯ В ОРГАНИЗАЦИЯХ ОБЩЕСТВЕННОГО ПИТАНИЯ
}

\begin{abstract}
Аннотация. В статье рассмотрены некоторые проблемы учетного обеспечения в организациях общественного питания, обуславливающие необходимость создания в них многофункциональной учетной системы, интегрированной в общую систему управления организацией. Разработаны требования для такой системы. Для целей управленческого учета предложено использование учета по центрам ответственности, план счетов и методика для его применения.
\end{abstract}

Ключевые слова: управленческий учет, учетная система, организации общественного питания, учет по центрам ответственности.

Введение. Отрасль общественного питания в Российской Федерации успешно функционирует и продолжает развитие, несмотря на отдельные отрицательные тенденции в отечественной экономике. Так, после 2008 года, многие организации общественного питания трансформировались из заведений высокой ценовой категории в более доступные, переориентировались на массового потребителя. Последующие события 2014-2015 годов повлекли за собой существенные изменения, как в ассортименте, так и в ценах импортных продуктов питания, что, в свою очередь, вызвало переформатирование организаций общественного питания, переориентацию их кухонь $[1,2]$.

Конкуренция среди организаций общественного питания практически всех категорий, за исключением, возможно, лишь среди заведений VIP-класса, достаточно выражена. Как же занять свое место на этом рынке и выдерживать конкуренцию? Множество факторов оказывает влияние на успешность деятельности, но одним из ключевых моментов в функционировании и управлении организацией об- щественного питания является обеспечение руководства качественной учетной информацией.

Основная часть. Ведение бухгалтерского учета организациями общественного питания осуществляется в соответствии с действующим законодательством и нормативами. Отличительной особенностью крупных организаций сферы общественного питания является одновременное осуществление трех видов деятельности: производство, торговля и услуги, что обуславливает широкий и разнообразный спектр затрат. Организациями общественного питания повсеместно применяется нормативный метод калькуляции себестоимости блюд [3, 4].

Данный метод позволяет четко сформировать себестоимость блюд, контролировать ее, планировать поставки продуктов (сырья), оптимизировать остатки сырья на складе, планировать его предстоящие расходы. Однако при применении только нормативного метода калькуляции имеется существенный недостаток - все остальные затраты организации учитываются в общей массе, что серьезно затрудняет их анализ и принятие последующих 
управленческих решений. Единой модели или концепции «управленческого учета, по мнению авторов, в организациях общественного питания в России на сегодняшний день нет» $[5,6]$, существуют лишь отдельные разработки о применении того или иного метода учета и расчета себестоимости продукции.

Исходя из вышесказанного, приходим к выводу, что организации общественного питания нуждаются в создании и внедрении учетной системы, включающей в себя, помимо финансового учета, управленческий учет с применением альтернативных методов учета затрат и калькуляции себестоимости продукции. При создании учетной системы организации, можно предложить следующие этапы:

1) Определение финансовой структуры предприятия путем выделения и классификации центров финансовой ответственности [7].
2) Разработка состава, содержания и форматов управленческой отчетности.

3) Разработка классификаторов управленческого учета.

4) Разработка методов управленческого учета затрат и калькулирования себестоимости продукции.

5) Разработка управленческого плана счетов и порядка отражения типовых хозяйственных операций [8].

6) Разработка внутренних положений и инструкций, регламентирующих ведение управленческого учета.

7) Проведение организационных изменений в фирме, обучение персонала.

8) Автоматизация управленческого учета [9].

Создавая учетную систему организации, следует руководствоваться следующими требованиями (табл. 1).

Таблица 1. Базовые требования, предъявляемые к учетной системе организации

\begin{tabular}{|c|c|}
\hline Лаконичность & Информация должна быть краткой и конкретной. \\
\hline Точность & Информация должна быть без ошибок и искажений \\
\hline Своевременность & $\begin{array}{l}\text { Информация предоставляется в обозначенный срок, в зависимости } \\
\text { от необходимости }\end{array}$ \\
\hline Сопоставимость (сравнимость) & $\begin{array}{l}\text { Информация должна быть сопоставимой (сравнимой) по конкрет- } \\
\text { ным показателям }\end{array}$ \\
\hline Объективность и полнота & Информация должна быть непредвзятой, полной и без изъятий \\
\hline Достоверность & Информация должна быть достоверной и проверяемой \\
\hline Уместность & $\begin{array}{l}\text { Информация должна полностью соответствовать цели ее } \\
\text { формирования. }\end{array}$ \\
\hline Рациональность & $\begin{array}{l}\text { Себестоимость информации не должна превышать выгоду от ее } \\
\text { использования }\end{array}$ \\
\hline Адресность & Информация должна быть направлена конкретным пользователям. \\
\hline Комфортность & $\begin{array}{l}\text { Информация должна предоставляться пользователям в удобном для } \\
\text { понимания виде }\end{array}$ \\
\hline
\end{tabular}

Источник: авторская разработка

Одним из эффективных методов учета затрат организации для целей управленческого учета является учет по центрам ответственности (ЦО). Целью учета по центрам ответственности является обобщение данных об издержках обращения и результатов деятельности по каждому центру ответственности для того, чтобы возникающие отклонения (от плана, норматива) можно было бы отнести на ответственное лицо $[10,11]$. Вместе с тем, система учета по ЦО позволяет определять издержки обращения в конкретных элементах (структурах) организации и эффективность их деятельности для последующего управленческого решения. Учитывая специфику деятельности организаций общественного питания, применение указанного метода в учетной системе должно дать заметный эффект.
В зависимости от функций и задач структурного подразделения, полномочий и ответственности их управляющих в организациях выделяются управленческие структурные подразделения: центр прибыли, центр инвестиций, центр доходов, центр затрат [12]. Их руководители несут непосредственную ответственность за выполнение обозначенных задач и достижение поставленных целей.

В организациях общественного питания «обычно выделяются следующие центры ответственности:

- центр затрат, основная цель которого минимизация затрат и издержек обращения, в нем выделяют центр нормативных и управленческих затрат;

- центр доходов, основная цель которого состоит в максимизации доходов предприятия;

- центр прибыли, основная цель которого 
Таблица 2. Структура центров ответственности организаций общественного питания

\begin{tabular}{|l|c|c|}
\hline $\begin{array}{l}\text { Наименование центра } \\
\text { ответственности }\end{array}$ & Ответственные & счет \\
\hline $\begin{array}{l}\text { Центр управленческих и общих } \\
\text { затрат }\end{array}$ & Администрация организации & 30 «Общие затраты» \\
\hline $\begin{array}{l}\text { Производство (центр нормативных } \\
\text { затрат) }\end{array}$ & $\begin{array}{c}\text { Шеф-повар, су-шеф, зав. } \\
\text { производством }\end{array}$ & $\begin{array}{c}31 \text { «Затраты на основное } \\
\text { производство» }\end{array}$ \\
\hline $\begin{array}{l}\text { Обеспечение (центр обеспечения } \\
\text { производста) }\end{array}$ & $\begin{array}{c}\text { Зав. складом, экспедитор-закуп- } \\
\text { щик, администрация }\end{array}$ & $\begin{array}{c}32 \text { «Общепроизводственные } \\
\text { затраты» }\end{array}$ \\
\hline Продажи (центр доходов) & Старший смены официантов & 33 «Затраты на продажу» \\
\hline Центр прибыли & Менеджмент организации & 34 «Затраты на менеджмент» \\
\hline
\end{tabular}

достижение оптимального соотношения доходов и расходов предприятия, увеличение показателей прибыльности и рентабельности предприятия общественного питания» [13].

В этой связи авторы предлагают следующую структуру центров ответственности (табл. 2).

На основании «Инструкции по применению плана счетов бухгалтерского учета финансово-хозяйственной деятельности организаций», мы можем использовать внутреннюю систему счетов для ведения управленческого учета с применением группы счетов 20-39. В этой связи предлагаем использовать счета 20 - 29 для группировки затрат для целей финансового учета, счета 30 - 34 для целей управленческого учета. Рабочий план счетов должен быть утвержден в учетной политике организации. Перечень счетов для бухгалтерского учета основывается на требовании ПБУ 10/99 «Расходы организации», в котором установлено, что: «При формировании расходов по обычным видам деятельности должна быть обеспечена их группировка по элементам».

Таблица 3. План счетов и корреспонденция счетов для целей финансового и управленческого учета в организациях общественного питания

\begin{tabular}{|c|c|c|c|}
\hline № & $\begin{array}{c}\text { Содержание хозяйственной опе- } \\
\text { рации (финансовый учет) }\end{array}$ & Дебет & Кредит \\
\hline 1 & Себестоимость блюд & 20 «Основное производство» & 41 «Товары на складе» \\
\hline 2 & $\begin{array}{l}\text { Вознаграждения работникам ос- } \\
\text { новного производства }\end{array}$ & $\begin{array}{c}24.1 \text { «Вознаграждения работникам } \\
\text { основного производства» } \\
24.2 « \text { Страховые взносы во внебюд- } \\
\text { жетные фонды» }\end{array}$ & $\begin{array}{c}70 \text { «Расчеты с персоналом по } \\
\text { оплате труда» } \\
69 \text { «Расчеты по социальному } \\
\text { страхованию» } \\
\end{array}$ \\
\hline 3 & $\begin{array}{l}\text { Вознаграждения работникам } \\
\text { администрации }\end{array}$ & $\begin{array}{c}24.3 \text { «Вознаграждения работникам» } \\
24.4 \text { «Страховые взносы внебюд- } \\
\text { жетные фонды» }\end{array}$ & $\begin{array}{c}70 \text { «Расчеты с персоналом по } \\
\text { оплате труда» } \\
69 \text { «Расчеты по социальному } \\
\text { страхованию» }\end{array}$ \\
\hline 4 & Амортизация ОС и НМА & 22 «Амортизация» & $\begin{array}{c}02 \text { «Амортизация основных } \\
\text { средств» } \\
05 \text { «Амортизация нематериаль- } \\
\text { ных активов» }\end{array}$ \\
\hline 5 & $\begin{array}{l}\text { Затраты на инвентарь, спе- } \\
\text { цодежду, аренду кухонного } \\
\text { оборудования }\end{array}$ & $\begin{array}{c}25 \text { «Общепроизводственные } \\
\text { расходы» }\end{array}$ & $\begin{array}{c}10 \text { «Материалы» } \\
60 \text { «Расчеты с поставщиками и } \\
\text { подрядчиками» } \\
76 \text { «Расчеты с разными дебитора- } \\
\text { ми и кредиторами» }\end{array}$ \\
\hline 6 & $\begin{array}{l}\text { Аренда помещений, коммуналь- } \\
\text { ные платежи, и т.п. }\end{array}$ & 26 «Общехозяйственные расходы» & $\begin{array}{c}60 \text { «Расчеты с поставщиками и } \\
\text { подрядчиками» }\end{array}$ \\
\hline 7 & $\begin{array}{l}\text { Расходы на продажу (вознаграж- } \\
\text { дения работникам - официанты, } \\
\text { бармены, хостесс), обслуживание } \\
\text { ККТ }\end{array}$ & 44 «Расходы на продажу» & $70,69,60$ \\
\hline 8 & $\begin{array}{l}\text { Обобщение затрат по окончании } \\
\text { периода }\end{array}$ & 27 «Обобщенные затраты» & $30,31,32,33,34$ \\
\hline
\end{tabular}




\begin{tabular}{|c|c|c|c|}
\hline 9 & Себестоимость продаж & 90.2 «Продажи» & 27 «Обобщенные затраты» \\
\hline 10 & Продажа блюд & $\begin{array}{c}50.1 \text { «Касса организации» } \\
51 \text { «Расчетный счет» }\end{array}$ & 90.1 «Продажи» \\
\hline 11 & $\begin{array}{l}\text { Центр управленческих и общих } \\
\text { затрат }\end{array}$ & 30 «Общие затраты» & $24.3,24.4,26$ \\
\hline 12 & $\begin{array}{l}\text { Производство (центр норматив- } \\
\text { ных затрат) }\end{array}$ & $\begin{array}{c}31 \text { «Затраты на основное } \\
\text { производство» }\end{array}$ & $20,24.1,24.2$ \\
\hline 13 & $\begin{array}{l}\text { Обеспечение (центр обеспечения } \\
\text { производства) }\end{array}$ & $\begin{array}{c}32 \text { «Общепроизводственные } \\
\text { затраты» }\end{array}$ & 22,25 \\
\hline 14 & Продажи (центр доходов) & 33 «Затраты на продажу» & 44 \\
\hline 15 & Центр прибыли & 34 «Затраты на менеджмент» & $24.3,24.4$ \\
\hline 16 & Закрытие периода & 27 «Обобщение затрат» & $30,31,32,33,34$ \\
\hline
\end{tabular}

Предлагаемая методика учета затрат организации общественного питания позволит отразить их по местам возникновения, элементам, носителям и центрам ответственности для последующего анализа и управленческих решений. Необходимо заметить, что метод учета по центрам ответственности в организациях общественного питания даст экономический эффект при выполнении следующих условий:

1) продуманный состав центров ответственности;

2) план затрат по центрам, выбор затрат, возможность их уменьшения должны быть реальными;

3) взаимосвязь управленческой отчетности всех центров ответственности;
4) интегрированного функционирования учета по центрам ответственности с общей системой финансового учета.

Заключение. Учитывая сложившуюся ситуацию в сфере общественного питания, достаточно высокую конкуренцию, приходим к выводу, что создание в организациях общественного питания полноценной учетной системы является реальной необходимостью. Система должна быть многокомпонентной и многофункциональной, включающая в себя различные методы, одним из которых является метод учета затрат по центрам ответственности. Создание такой учетной системы в организациях общественного питания позволит обеспечить бизнес-процессы полноценной учетной информацией.

\section{Список использованных источников}

1. Алимова М.С. Построение и применение системы управленческого учета на предприятии общественного питания // Бухгалтерский учет и налоги в торговле и общественном питании, 2016. №;5. С. 28-46.

2. Зеленов В.В. Формирование системы управленческого учета в предприятиях общественного питания // Вестник университета, 2015. №10. С.24-26

3. Шихатов П.И. Некоторые аспекты управленческого учета в организациях общественного питания // Вестник Международного института экономики и права. 2016. № 3 (24). С. 43-50.

4. Гордиенко М.С. Анализ основных направлений налоговой политики Российской Федерации на 2015-2017 гг.// Экономика и практический менеджмент в России и за рубежом Материалы II Международной научно-практической конференции. Коломенский институт (филиал) Московского государственного машиностроительного университета: сборник. Под ред.: Маруков А.Ф. и др. 2015. С. 107-113.

5. Семенова Г.Н. Инновационное развитие экономики России // Вестник Московского государственного областного университета. 2011. № 1. С. 233-237.

6. Шихатов П.И. Развитие управленческого учета на предприятиях общественного питания // Экономика и управление: проблемы, решения. 2018. Т. 2. № 12. С. 92-96.

7. Калачева О.Н. Технология организации контроля // Вестник Российского государственного торгово-экономического университета (РГТЭУ). 2014. № 4 (84). С. 13-22.

8. Шихатов П.И. Некоторые аспекты управленческого учета в организациях общественного питания // Вестник Международного института экономики и права. 2016. № 3 (24). С. 43-50.

9. Косов М.Е., Иванова Я.Я. Казначейское сопровождение государственных контрактов // РИСК: Ресурсы, информация, снабжение, конкуренция. 2017. № 3. С. 200-206. 
10. Малицкая В.Б., Чиркова М.Б. Концептуальные аспекты учета обесценения финансовых вложений в соответствии с Российскими и международного признанными стандарати // British Journal of Science, Education and Culture. 2015. Т. 3. № 1 (7). С. 160-166.

11. Коноваленко И.Е., Галайда А.М., Сафонова Э.Г. Сборник практических заданий по дисциплине «Бухгалтерский финансовый учет». - Москва, -2014 г.

12. Агапова А.А. [и др.] Налоги и налогообложение. Учебник для прикладного бакалавриата: Москва, Издательство: ООО «Издательство ЮРАЙТ» , - С. 503

13. Петров А.М., Мельникова Л.А. Теоретические аспекты учета калькулирования себестоимости продукции // Экономические науки. 2013. № 102. С. 145-148.

\section{Malitskaya Victoria Borisovna}

Doctor of Economics, Professor, Department of Accounting and Taxation

Plekhanov Russian University of Economics, Russian Federation, 117997, Moscow, Stremyanny lane, 36

E-mail:vmrussian@yandex.ru

\section{Shikhatov Pavel Ivanovich}

PhD student, Department of Accounting and Taxation

Plekhanov Russian University of Economics

Russian Federation, 117997, Moscow, Stremyanny lane, 36,

Senior lecturer, Department of Economic Theory and World Economy

International Institute of Economics and Law

Russian Federation, Moscow, 105082 Rubtsovskaya nab. 3/1

E-mail:pulivan@yandex.ru

\section{CURRENT PROBLEMS OF ACCOUNTING SUPPORT IN PUBLIC CATERING ORGANIZATIONS}

Summary. The article deals with some problems of accounting in catering organizations, necessitating the creation of a multifunctional accounting system integrated into the overall management system of the organization. Requirements for such a system have been developed. For the purposes of management accounting, the use of accounting for responsibility centers, the chart of accounts and the methodology for its application are proposed.

Keywords: management accounting, accounting system, public catering organizations, accounting by responsibility centers. 